\title{
TÜRKİYE VE AVRUPA BİRLİĞI’'NE ÜYE BAZI ÜLKELERİN EĞİTIM YAPILARI VE YÖNETİMLERI AÇISINDAN KARŞILAŞTIRILMASI
}

\author{
Sefer ADA* \\ Z. Nurdan BAYSAL ${ }^{* *}$
}

\section{Özet:}

Karşılaştırmalı eğitim kapsamında yer alan bu çalışmanın amacı, Türkiye ile on AB ülkesini (Almanya, Avusturya, Danimarka, Finlandiya, Fransa, İngiltere, İspanya, İsveç, Portekiz, Yunanistan); eğitim basamakları okulöncesi eğitim, zorunlu eğitim, ortaöğretim, yükseköğretim- ve yetişkin eğitimlerine ek olarak eğitim bakanlıkları, okul yönetimleri, eğitimin finansmanı, teftişi ve öğretmen yetiştirme programları açısından incelemektir. Ele alınan ülkeler eğitim yapıları ve yönetimleri açısından benzerlikler taşımakla birlikte bir takım farklılıklara sahiptir. Örneğin, söz konusu tüm ülkelerde okul öncesi eğitim zorunlu eğitim kapsamında değilken, zorunlu eğitimin süreleri açısından ülkeler çeşitlilik sergilemektedir. Türkiye on ülke ile karşılaştırıldığında zorunlu eğitim süresi en kısa olan ülkedir. Çalışmada yer alan ülkelerde lise türleri, üniversiteye giriş düzenleri açısından çeşitli uygulamalar söz konusudur. Tüm ülkelerde üniversite düzeyinde ön lisans, lisans ve lisansüstü programlar mevcuttur. Eğitimde yetkili ve sorumlu kurumların sayısı, okul yöneticilerinin unvanları ülkeden ülkeye değişmektedir. Eğitimin finansmanı açısından ülkeler değerlendirildiğinde ele alınan ülkelerin tümünün eğitime Türkiye'den daha fazla kaynak ayırdığı görülmektedir. Okul denetiminde ise Finlandiya' da ele alınan diğer ülkelerden farklı olarak ayrı bir okul denetim sisteminin olmaması dikkat çekicidir. Öğretmen yetiştiren okulların öğrenim süreleri Türkiye'de olduğu gibi 4 ile 5 yıl arasında değişmekle birlikte -örneğin Finlandiya'da- ögretmenlik yapabilmek için mutlaka yüksek lisans mezuniyet derecesini almış olmak gerekmektedir. Çalışmada incelenen Almanya, İsveç eğitim sistemi,

\footnotetext{
* Prof. Dr., Marmara Üniversitesi Atatürk Eğitim Fakültesi İlköğretim Bölümü Sınıf Öğretmenliği Anabilim Dalı

** Yrd. Doç. Dr., Marmara Üniversitesi Atatürk Eğitim Fakültesi İlköğretim Bölümü Sınıf Öğretmenliği Anabilim Dalı
} 
özellikle de son yıllarda uluslar arası sınavlarda büyük başarı gösteren Finlandiya eğitim sistemi özgün olma özelliğini taşıyan ülkelerin başında gelmektedir. Çalışmadan elde edilen verilere bağlı olarak Türkiye için zorunlu eğitim süresinin, ortaöğretimden üniversiteye geçiş koşullarının yeniden ele alınması, eğitime ayrılan kaynağın arttırılması, teftiş sisteminin iyileştirilmesi gibi önerilerde bulunulmuştur.

Anahtar kelimeler: Karşıllaştırmalı eğitim, eğitim yapısı, eğitim yönetimi, Avrupa Birliği Ülkeleri

\section{Abstract:}

The aim of this study which is based on comparative education is to examine Turkey and ten EU countries (Germany, Austria, Denmark, Finland, France, England, Spain, Sweden, Portugal, Greece) in terms of educational levels - preschool education, obligatory education, secondary education, higher education and adult education - and in addition to that, in terms of educational ministries, school administrations, education finance, inspection and teacher education programs. Although these countries have some common similarities as for their educational systems and administrations, they have some differences. For example, as not all these countries propose compulsory pre-school education, they how some variances in their extension of compulsory education. Turkey, when compared to the other ten countries, has the shortest compulsory education period. The countries involved in this study have some different applications in high school types and university acceptance rules. In all these countries, there are pre-graduate, undergraduate and graduate programs at university level. The number of authorities in education and responsible institutions and the title of school administrators differ from country to country. When examined in terms of educational finance, all these countries are observed to finance education much more than Turkey. As for school inspection, it is surprising that there is no school inspection system in Finland as opposed to the other countries. While the instruction time in teacher education schools ranges between 4 to 5 years as it is in Turkey, it is obligatory to have a graduate degree to be able to become a teacher, as in Finland. The educational systems of Germany, Sweden and Finland - which has exhibited a great success at international exams in recent years - are the leading countries that have some original perspectives. Based on the data gathered from this study, it has been suggested that compulsory education period and university acceptance rules should be rediscussed, the allocation of finance to education should be increased and inspection system should be improved. 
Keywords: Comparative education, educational system, educational management, European Union Countries.

\section{Giriş}

Her toplum varlığını sürdürebilmek ve gelecekte kendisine yeterli sağlam bir yapı oluşturabilmek için koşullarına uygun ekonomik, sosyal, siyasal, kültürel yapısını, özellikle de eğitim sistemlerini oluşturmak zorundadır. Her sistem önemli ve vazgeçilmezdir. Fakat eğitim tüm sistemlerin içinde en önemli olanıdır. Çünkü eğitimin belirleyici ve etkileyici özelliği diğer sistemlere göre daha fazladır. En pahalı ve en kârlı olan eğitim sistemi eğer yanlış oluşturulur ve uygulanırsa diğer tüm sistemler de bundan olumsuz yönde etkilenir. Sistemin doğruluk ya da yanlışlı̆̆, ihtiyaçlara cevap vermesi ve gelecek için gelişmeye uygun ortamın oluşmasına bağlıdır. Geri kalmış ya da gelişmiş olan ülkelerin bugünkü durumu geçmişteki eğitim sisteminin sonucudur. Bir sistem hem alt hem de üst başka sistemlere bağlıdır ve onlarla etkileşim içindedir. Her sistem doğal olarak içinden çıktığı toplumun ürünüdür. Yani toplumun tarihsel gelişimi, kültürü, ekonomisi, siyasal yapısı vb. sistemin oluşumunu ve işleyişini etkiler. Her toplum kendi iç ve dış dinamikleri ile çeşitli alt ve üst sistemlerini oluştururken geçmişteki etkileri gelecekteki hedefleri göz önünde bulundurmak zorundadır.

Karşılaştırmalı eğitim çalışmalanının temelleri özellikle XXI. yüzyıldan itibaren hız kazanmıştır, sürekli de gelişmektedir. Edmund King'in "Her kurulan sistem hiçbir zaman uzun süreli kalıcı olmaz aksine sürekli yenilenir" sözü de bunu doğrular niteliktedir. Claxton (1998: 70) son 20 senedir sürekli bir değişim ve gelişim çağına girildiğini belirtmiştir. Rogers (1993: 77) ve Brown (1999: 19-20) da karşılaştırmalı eğitim çalışmalarıyla ülkelerdeki eğitim anlayışının ve eğitim sistemlerinin geliştiğini savunmuştur.

Lawrence Stenhouse (1979: 5) karşılaştırmalı eğitim çalışmalarıyla farklı kültürlerin tanınabileceğini vurgulamış aynı zamanda külttürel öğeleri yorumlamayı sağlayacağını da belirtmiştir. Stenhouse (1979: 18)'a göre, karşılaştırmalı eğitim bilimi bir pozitivist sosyal bilim dalıdır. Toplumlanın farklı eğitim politikalarını karşılaştırmasını sağlar. Schriewer (2000: 20) karşılaşıırmalı eğitim çalışmalarının farklı eğitim ideolojilerini, farklı sosyokültürel amaçları tanımayı ve yorumlamayı sağlayacağı konusunda hemfikir olmuştur. Uluslar arası kültürel tanımların oluşmasını destekleyeceğini belirtmiştir. Ülkelerin eğitim sistemlerindeki zayıf ve güçlü yönleri keşfedip diğer ülkelerle karşılaştırıp yorumlayarak geleceğe yönelik gelişim ve değişim hareketlerini destekleyeceğini eklemiştir (aktaran Broadfoot, 2000). 
$\mathrm{Bu}$ çalışma karşılaştırmalı eğitim kapsamında değerlendirilebilir. Bu yüzden karşılaştırmalı eğitimin amaçlarına hizmet etmesi amaçlanmaktadır. Karşılaştırmalı eğitim amaçları ayrıntılı bir şekilde şöyle sıralanabilir:

- Eğitim sistemlerine, sorunlarına ve etkinliklerine ilişkin geçerli bilgiler elde etmek;

- Yerel, ulusal ve uluslar arası bir konu olan eğitimde, bir dizi hipotezi, gerekli yöntem ve teknikleri, yorum için gerekli esasları ve sonuçları geliştirmek;

- Eğitime etkin olan etmenlerin, çeşitli ülkelerdeki evrimini ve görünümünü inceleyerek, eğitim politikasının saptanmasına yardım edecek görüşü kazandırmak;

- Bir ülkenin kendi eğitim sistemini geliştirmesi için kuramsal ve uygulamalı olarak katk1da bulunmak.

$\mathrm{Bu}$ alanın ayrıca, kültür ufkunu genişletmek, uluslar arası gerginliği azaltmak, eğitimi bilim ve kültür süreci olarak zenginleştirmek, uluslar arası anlayışa katkıda bulunmak ile diğer ülkelerle dostça ve açık bir iletişim kurmak gibi amaçlarına (Lauweyers, Varış \& Neff, 1979; 6; Noah, 1984: 552; Ruscoe \& Nelson, 1964: 390'dan aktaran Demirel, 1998: 8) globalleşmeyi desteklemek ve tüm ülkelere yönelik uluslar arası bir eğitim anlayışının doğmasını sağlamak gibi amaçlar da eklenebilir (Sutton, Post, Merkxi \& diğerleri, 2006).

Belirli anlayışı paylaşmak amacıyla kurulan çeşitli işbirlikleri, ortak ya da benzer programlar uygulayabilirler. Bunun en somut örneğini Avrupa Birliği (AB) oluşturmaktadır. Türkiye bu birliğe girmek amacıyla; 31 Temmuz 1959'da başvuruda bulunmuştur. 12 Eylül 1963'de Ortaklık Anlaşması'nın imzalanmasıyla Türkiye 1999'da Aday Ülke statüsü almıştır. Türkiye, 2001'de Katılım Ortaklık Belgesiyle, nihayet 2005'deki tam üyelik müzakerelerinin başlamasıyla yolunu, hedefini belirlemiştir.

AB'nin temel hedefi; üye ülkeler arasındaki işbirliğini ve dayanışmayı sağlamak amacıyla ilgili ülkelerin vatandaşları arasındaki karşılıklı anlayışı özendirmek ve Avrupalılık bilincini aşılamak, bu süreçte öğretmen ve ögrencilerin Ar-Ge alanlarına etkin katılımlarını sağlamaktır (Millî Eğitim Bakanlığ1 [MEB], 2006: 15). Türkiye, AB'nin oluşturduğu; Genel Eğitim (Socrates), Meslekî Eğitim (Leonardo da Vinci) ve Gençlik (Youth) programlarına katılarak öngörülen amacı ve uyum sürecini gerçekleştirmeye çalışmaktadır. Yarım asırdan fazla bir zamandır başlanan bu süreçte, Türkiye kendi koşullarına göre uygun programlar geliştirmekten çok, ilgili 
bazı ülkelerin sistemlerine uygun-benzer anlayışları gerçekleştirme gayreti içine girmiştir. $\mathrm{Bu}$ çalışmada Türkiye ile on $\mathrm{AB}$ ülkesinin (Almanya, Avusturya, Danimarka, Finlandiya, Fransa, İngiltere, İspanya, İsveç, Portekiz, Yunanistan); eğitim basamakları -okulöncesi eğitim, zorunlu eğitim, ortaöğretim, yükseköğretim- ve yetişkin eğitimlerine ek olarak Eğitim Bakanlıkları, okul yönetimleri, eğitimin finansmanı, eğitimin teftişi ve öğretmen yetiştirme programları ele alınarak incelenmiştir.

\section{Eğitim Basamakları}

Türkiye ve on $\mathrm{AB}$ ülkesinde eğitim basamakları, değişik öğrenim süreli okul öncesinden başlayarak üniversiteye kadar, geçişlerde farklı kriterlerin uygulandığı bir yapıya sahiptir. Tablo 1, Türkiye ile $\mathrm{AB}$ ülkelerinin okulöncesi eğitim basamağının yaş ve zorunlu eğitim kapsamında ele alınıp alınmadığını göstermektedir.

\begin{tabular}{lll}
\hline Tablo I & & \\
Türkiye ve & AB & ülkelerinde okul öncesi eğitim \\
\hline Ülke & Yaș gubu & Zorunlu \\
\hline Türkiye & $5-6$ & - \\
Almanya & $3-6$ & - \\
Avusturya & $3-6$ & - \\
Danimarka & $0 / 6-7$ & - \\
Finlandiya & $1-7$ & - \\
Fransa & $2-6$ & - \\
Ingiltere & $3-5$ & - \\
İspanya & $0 / 3-6$ & - \\
İsveç & $1-7$ & - \\
Portekiz & $3-6$ & - \\
Yunanistan & $3.5-5.5$ & - \\
\hline
\end{tabular}

(-: değil)

Kaynak: Erginer, 2006; Lappalainen, 2006; Moon, 2001; Öz, 2001; Ültanır, 2000; Karacaoğlu \& Çabuk, 2002; Pökön, 2003; Yıldırım, 2008'den yararlanılarak oluşturulmuştur.

Tablo 1'de görüldüğgu gibi okul öncesi eğitim Türkiye'de 5-6 yaş arasında zorunlu değildir. Ele alınan $\mathrm{AB}$ ülkelerinde de okul öncesi eğitim zorunlu eğitim kapsamında yer almamaktadır. Okul öncesi eğitim genellikle ilköğretime hazırlık niteliğinde olup ele alınan ülkelerde öncesinde çocukların bakımı ve eğitimini üstlenen çeşitli kamu ve özel kurumlar bulunmaktadır. Tablo 2'de kamu ve özel eğitim kurumlarında 4 yaşın altında okullaşma oranları görülmektedir. 


\begin{tabular}{|c|c|}
\hline \multicolumn{2}{|c|}{$\begin{array}{l}\text { Tablo } 2 \\
\text { Türkiye ve AB ülkelerinde } 4 \text { yaşın altında } \\
\text { okullaşma oranlart (2002) }\end{array}$} \\
\hline Ülke & Okullaşma oranı \\
\hline Türkiye & - \\
\hline Almanya & 80.3 \\
\hline Avusturya & 63.8 \\
\hline Danimarka & 86.9 \\
\hline Finlandiya & 39.6 \\
\hline Fransa & 119.7 \\
\hline İngiltere & 81.2 \\
\hline İspanya & 112.5 \\
\hline İsveç & 75.5 \\
\hline Portekiz & 66.4 \\
\hline Yunanistan & 28.5 \\
\hline
\end{tabular}

Kaynak: OECD, 2004'den aktaran Çalışkan Maya, 2006.

Tablo 2 incelendiğinde $\mathrm{AB}$ ülkelerinde 4 yaşın altında nüfusun \% 75.4'ünün okullaştığı görülmektedir. Bu oran ile $\mathrm{AB}$ ülkelerinin 4 yaşın altında okullaşma oranlanı bakımından oldukça iyi durumda olduğu vurgulanabilir. Türkiye'de ise 4 yaş okullaşma oranına ilişkin veri bulunmamaktadır. Tüm ülkelerde çağdaş yaşamın gereği olarak, zorunlu eğitimin parasız olmasına karşılık öğrenim süresi, yaş sının bakımından farklılıklar göstermektedir. Tablo 3'de Türkiye ve AB ülkelerinde zorunlu eğitim yaş ve süreleri yer almaktadır.

\begin{tabular}{|c|c|c|}
\hline \multicolumn{3}{|c|}{$\begin{array}{l}\text { Tablo } 3 \\
\text { Türkiye ve AB ülkelerinde zorunlu eğitim }\end{array}$} \\
\hline Ülke & Yaş grubu & Süre (yıl) \\
\hline Türkiye & $6-14$ & 8 \\
\hline Almanya & $6-18$ & 12 \\
\hline Avusturya & $6-15$ & 9 \\
\hline Danimarka & $7-16$ & 9 \\
\hline Finlandiya & $7-16$ & 9 \\
\hline Fransa & $6-16$ & 10 \\
\hline İngiltere & $5-16$ & 11 \\
\hline İspanya & $6-16$ & 10 \\
\hline İsveç & $6-16$ & 9 \\
\hline Portekiz & $6-15$ & 9 \\
\hline Yunanistan & $6-14$ & 9 \\
\hline
\end{tabular}

Kaynak: Ada, 2007; Çalışkan Maya, 2006; Erginer, 2006; Eurydice, 2005; Gültekin, 1998; Laycock, 2002; Nothern Ireland Goverment Department of Education, 2001; Education System in Finland, 2006'dan yararlanılarak oluşturulmuştur. 
Tablo 3'de görüldüğü gibi çalışmanın kapsamı içerisinde yer alan ülkelerde en düşük zorunlu eğitim süresi 8 yıl, en yüksek zorunlu öğrenim süresi ise 12 yıldır. Yaş itibariyle de okula başlama yaşı en düşük 5, zorunlu eğitimi bitirme yaşı en yüksek $18^{\prime}$ dir. $\mathrm{AB}$ ülkelerinde zorunlu öğretim kapsamında öğrenciler 9-12 yıl arasında değişen sürelerle eğitim görmektedir. Bazı ülkelerde zorunlu eğitimi tamamlayamayan öğrencilere ek süre verilmektedir. Örneğin, Türkiye'de bu ek süre iki yıldır. AB ülkeleri ile karşılaştırıldığında Türkiye zorunlu eğitim süresi en az olan ülkedir. Tablo 4, zorunlu eğitim yaşlarını içine alan $05-14$ ve $15-19$ yaş nüfusu için okullaşma oranlarını göstermektedir.

\begin{tabular}{|c|c|c|}
\hline \multicolumn{3}{|c|}{$\begin{array}{l}\text { Tablo } 4 \\
\text { Türkiye ve AB ülkelerinde } 05-14 \text { ve } 15-19 \text { yaş yüfusu } \\
\text { okullaşma oranlarl (2002) }\end{array}$} \\
\hline Ülke & 05-14 yaş nüfusu & 15-19 yaş nüfusu \\
\hline Türkiye & - & - \\
\hline Almanya & 97.5 & 89.2 \\
\hline Avusturya & 98.9 & 77.1 \\
\hline Danimarka & 99.1 & 81.8 \\
\hline Finlandiya & 94.4 & 85.0 \\
\hline Fransa & 101.1 & 86.7 \\
\hline İngiltere & 98.9 & 76.8 \\
\hline İspanya & 103.8 & 80.4 \\
\hline İsveç & 98.2 & 86.2 \\
\hline Portekiz & 106.0 & 70.9 \\
\hline Yunanistan & 96.3 & 82.6 \\
\hline
\end{tabular}

Kaynak: OECD, 2004'den aktaran Çalışkan Maya, 2006.

Tablo 4'te yine Türkiye için 05-14 yaş ve 15-19 yaş nüfuslarında okullaşma oranı verileri bulunmazken $\mathrm{AB}$ ülkeleri nüfusa göre ortalama okullaşma oranları 05-14 yaş nüfusun \%99.4'ünün, 15-19 yaş nüfusunun ise \%81.7'sinin okullaştı̆g görülmektedir.

Yıllık öğretim işgünü çalışmaya konu olan çeşitli ülkelerde farklılık arz etmektedir. Örneğin, Almanya'da ortaöğretim I. devre için 180-208 arasında, Fransa'da 158, İngiltere'de 190, Türkiye'de ise 180 işgünüdür. İlköğretimde haftalık ders saatleri de ülkelere göre değişiklik göstermektedir. Örneğin, Danimarka'da 20-28, Almanya'da 17-28, Yunanistan'da 23-32, İspanya'da 25, Fransa'da 26, Portekiz'de 25 ve Türkiye'de 30 olarak ders saatleri düzenlenmiştir. İlköğretimde bir ders saatinin süresi ise çalışmaya konu olan ülkelerde genellikle 40 ile 50 dakika arasında değişmektedir. Örneğin, Danimarka ve Almanya'da 45 dakika, Yunanistan'da 40-50 dakika, Türkiye'de 40 dakika iken Fransa ve Portekiz'de ise süre konusunda öğretmen serbest bırakılmıştır. Her 
öğretmen kendi sınıfının öğrenim süresini kendisi ayarlamaktadır. Söz konusu ülkelerde haftalık öğretim günü genellikle 5 gün olmakla birlikte Almanya'da ve Portekiz'de bazen 6 gün olmaktadır. Söz konusu AB ülkelerinde ylllık öğretim günü 180 ile 200 gün arasında değişmektedir (Gültekin, 1998).

Sömestr sayısı bazı ülkelerde 2, bazı ülkelerde ise 3 ya da 4 şeklinde düzenlenmiştir. Türkiye'de tarım toplumu yapısının özelliğini arz eden bir düzenlemeye gidilmiş, hasat zamanı denk gelen yaz tatili uzun tutulmuştur. Ülkemizde yaz tatilinin süresi yaklaşı 3 ay iken $\mathrm{AB}$ ülkelerinde ise genellikle 1.5 ay ile 2.5 ay arasında değişmektedir.

Bazı ülkelerde temel eğitimden bir üst eğitim kurumu olan genel ya da meslekî okullara geçiş için ya not ortalaması ya da öğrencilerin ilgi ve yeteneklerini ölçen değişik sınav sistemleri uygulanmaktadır. Ortaöğretim kendi içerisinde iki genel kategoriye ayrılmaktadır. Bazı ülkelerde mesleğe hazırlık programlarının uygulandığı liselerin yanında bir üst öğrenim kurumu olan yüksek okullara ögrenci hazırlayan okullar da mevcuttur. Örneğin; Türkiye'de genel liseler, Almanya'da gymnasium gibi okullar bu kategoride sayılabilir. Gymnasium ilköğretimde ilgi, yetenek, çalışma ve başarısındaki gelişim sürecine göre yükseköğretim yapabilecek düzeyde bulunan öğrencilerin yönlendirildiği bir okuldur (Öz, 2001). Danimarka'da da gymnasium yükseköğretime hazırlayan üç yıllık programlardır. İsveç'te ise ortaöğretim 16-19 yaş grubunu kapsayan gymnasieskola adı verilen kurumlarda gerçekleştirilmektedir.

İngiltere'de ortaöğretim için resmi okullar (maintained schools), çok programlı okullar (comprehensive schools), gramer okulları (grammar schools), șehir teknoloji koleji (city technology college-CTC), sanat teknolojisi şehir koleji (city college for the technology of the arts-CTAS), ileri eğitim kolejleri (further education college) şeklinde siralanabilecek çeşitli okullar bulunmaktadır (DFES, 2004a). Finlandiya'da ortaöğretim II. devre genel ortaöğretim 16-19 yaş arası gençleri yüksek öğretime hazırlamaktadır. Bu okulların süresi üç yıl olmakla birlikte yetişkinlere de açık olan bu devre en az 2 en fazla 4 yılda tamamlanmak koşulu ile hizmet vermektedir. Ortaöğretimden yükseköğretime geçiş için farklı ülkelerde değişik uygulamalar yapılmaktadır. Tablo 5 'te Türkiye ve AB ülkelerinde ortaöğretimden yükseköğretime geçiş koşulları yer almaktadır. 
Tablo 5

Türkiye ve AB ülkelerinde ortaöğretimden yükseköğretime geçiş

\begin{tabular}{|c|c|}
\hline Ülke & Geçiş koşulu \\
\hline Türkiye & üniversite giriş sınavı \\
\hline Almanya & olgunluk sınavı (abitür) \\
\hline Avusturya & olgunluk sinavı \\
\hline \multirow[t]{4}{*}{ Danimarka } & Ortaöğretim sınavı (studenterksamen)/ \\
\hline & Yükseköğretim Hazırlık Sınavı-HF/ \\
\hline & Yüksek Ticaret Sınavı-HHX/ \\
\hline & Yüksek Teknik Sınavı-HTX birinden başarılı olmak \\
\hline Finlandiya & üniversite giriş sınavı \\
\hline Fransa & üniversite giriş sınavı (bakalorya) \\
\hline İngiltere & sertifikalar ile \\
\hline İspanya & lise not ortalaması+üniversite giriş sınavı+hazırlık sınıfı puanı \\
\hline İsveç & lise not ortalaması/üniversite standart giriş testi \\
\hline Portekiz & yetenek testleri/her kurumun açtığı özel sınavlar \\
\hline Yunanistan & kurumların kendi yaptığı giriş sınavları \\
\hline
\end{tabular}

Kaynak: Bentolila \& Jimeno, 1998; Eurydice, 2005; Eurydice, 2007; Eurydice, 2008a; Ministère Education Nationale, 2008; Ültanır, 2000'den yararlanılarak oluşturulmuştur.

Tablo 5 incelendiğinde Türkiye'de olduğu gibi AB ülkelerinin bazılarında da yükseköğretime öğrenci kabulünün sınav ile yapıldığı görülmektedir. Fakat AB ülkelerinin çoğunda yapılan sınav tek koşul olarak değerlendirilmemekte ayrıca öğrenciyi alma ilgili yükseköğretim kurumunun kararı ile gerçekleşmektedir. İsveç ve Portekiz gibi bazı ülkelerde yükseköğretime geçişte başka koşullara ek olarak yapılan bir takım testlerin sonuçları da göz önüne alınmaktadır. Üniversiteye giriş Türkiye'de tek bir sınav ile merkezden yapılırken Almanya, Fransa ve Ingiltere incelendiğinde öğrencilerin geçişte ortaöğretim başarı durumlarının ve her kurumun kendi belirlediği kriterlerin de geçerli olduğu görülmektedir (Kilimci, 2006).

Üniversitelerde ön lisans, lisans ve lisansüstü programlar yer almaktadır. Sisteme giriş için 1. sınıf hazırlık adı altında bazı okullarda programlar uygulanmakta sonrasında öğrenci kendi eğilimine göre farklı programlara yönelebilmektedir. Genellikle her ülkede ara elemanı yetiştirmek amacı ile 2 yıllık ön lisans programlı meslek yüksek okulları bulunmaktadır.

\section{Yetişkin Eğitimi}

Günümüzde teknoloji ve bilimsel alanda meydana gelen hızlı gelişmeler, bir insanın örgün eğitim çağında edinmiş olduğu bilgileri bütün yaşamı boyunca kullanmasının mümkün olamayacağını göstermiştir. $\mathrm{Bu}$ nedenle örgün eğitimin içinde, dışında ve yanında çeşitli ülkelerde düzenlenen 
yetişkin eğitim programlan da mevcuttur. $\mathrm{Bu}$ programlar ya ilgili bakanlıklar tarafından, ya yerel yönetimler tarafından ya da örgün eğitim kurumları tarafindan hazırlanmakta ve yürütülmektedir. Bazı ülkelerde Danimarka ve İsveç gibi- üniversitelerde yetişkinler için belirli bir kontenjan ayrılmaktadır. Yetişkin eğitimine yönelik programlar her ülkede ülkenin koşullarına uygun olarak farklı niteliklerde yapılmaktadır. Bazı ülkelerde yetişkin eğitimi programları meslek ağırlıklı, bazı ülkelerde kültür ve boş zamanı değerlendirme ağılıklı, bazı ülkelerde de tamamlama eğitimi niteliğinde düzenlenmektedir.

Tablo 6, AB ülkelerinde 20 yaş ve sonrası okullaşma oranlarını içermektedir.

\begin{tabular}{|c|c|c|c|}
\hline $\begin{array}{c}\text { Tablo } 6 \\
\text { Türkiye ve } A \\
20-29, \quad 30-3 \\
\text { oranlarl (2002) }\end{array}$ & $\begin{array}{l}\text { Bülkelerina } \\
\text { ve } 40 \text { ve }\end{array}$ & eri yaş nü & u okullaşma \\
\hline Ülke & $\begin{array}{c}20-29 \\
\text { yaş } \\
\text { nüfusu }\end{array}$ & $\begin{array}{c}\text { 30-39 } \\
\text { yaş } \\
\text { nüfusu }\end{array}$ & \begin{tabular}{l}
\multicolumn{1}{c}{40} \\
ve \\
üzeri yas \\
nüfusu \\
\end{tabular} \\
\hline Türkiye & - & - & - \\
\hline Almanya & 25.5 & 2.8 & 0.2 \\
\hline Avusturya & 17.0 & 3.1 & 0.3 \\
\hline Danimarka & 31.4 & 5.5 & 0.8 \\
\hline Finlandiya & 39.5 & 10.7 & 2.2 \\
\hline Fransa & 19.6 & 1.8 & - \\
\hline İngiltere & 26.8 & 16.2 & 8.3 \\
\hline İspanya & 23.3 & 2.6 & 0.4 \\
\hline İsveç & 33.6 & 14.1 & 3.5 \\
\hline Portekiz & 22.4 & 3.8 & 0.6 \\
\hline Yunanistan & 24.5 & 0.3 & - \\
\hline
\end{tabular}

Kaynak: OECD, 2004'den aktaran Çalışkan Maya, 2006.

Tablo 6 incelendiğinde $\mathrm{AB}$ ülkelerinde nüfusa göre ortalama 20-29 yaş nüfusun \%26.4'ünün, $30-39$ yaş nüfusun $\% 6.1$ 'inin ve 40 ve üzeri yaş nüfusun ülkelerin sekizinde $\% 2.1$ 'inin okullaştığı görülmektedir. Türkiye için ise bu yaşlar arası verilere rastlanmamaktadır.

\section{Eğitim Yönetimi}

Ele alınan ülkelerde eğitimde yetkili ve sorumlu kurumlar çeşitlilik arz etmekle birlikte bazı ülkeler merkezî bazılan yerel bazıları ise merkezî ve yerel yönetimin her ikisini de benimsemiş bulunmaktadır (Tablo 7). 
Tablo 7

Türkiye ve AB ülkelerinde eğitimin yönetim sekli ve yetkili/sorumlu kurumlar

\begin{tabular}{|c|c|c|}
\hline Ülke & Egritimde yetkili/sorumlu kurumlar & $\begin{array}{l}\text { Eğitimin yönetim } \\
\text { şekli }\end{array}$ \\
\hline Türkiye & Eğitim Bakanlığı & merkezî \\
\hline Almanya & $\begin{array}{l}\text { Eğitim Bakanlığı / Valilik / Ĕ̆itim } \\
\text { Yöneticiliği }\end{array}$ & yerel \\
\hline Avusturya & Eğitim, Bilim ve Kültür Bakanlı̆̆ı & merkezî \\
\hline Danimarka & $\begin{array}{l}\text { Sosyal İşler Bakanlığı }+ \text { Ĕgitim Bakanlığı }+ \\
\text { Kültür Bakanlığ }\end{array}$ & yerel \\
\hline Finlandiya & Ĕgitim Bakanlı̆̆ & merkezî \\
\hline Fransa & $\begin{array}{l}\text { Eğitim Bakanlığı + Araştırma ve Teknoloji } \\
\text { Bakanlığı+ Tarım ve Balıkçılık Bakanlığı } \\
\text { Çalışma ve Sosyal Güvenlik Bakanlığı } \\
\text { Gençlik, Spor ve Kültür Bakanlığı }\end{array}$ & merkezî \\
\hline İngiltere & $\begin{array}{l}\text { Eğitim Bakanlığı (Department for } \\
\text { Education and Skills-DFES) + Yerel Eğ itim } \\
\text { Kurumu (Local Education Authority-LEA) }\end{array}$ & merkezîtyerel \\
\hline İspanya & Eğitim ve Bilim Bakanlığı & merkezîtyerel \\
\hline İsveç & Eğitim ve Bilim Bakanlığı & merkezî̀+yerel \\
\hline Portekiz & Eğitim Bakanlığı & merkezî̀+yerel \\
\hline Yunanistan & Ulusal Eğitim ve Din İşleri Bakanlığı & merkezî \\
\hline
\end{tabular}

Kaynak: Diplôme National du Brevet, 2008; DFES, 2004b; Doğan, 2002; Erginer, 2006; Eurydice, 2008b; Lauwers \& diğerleri, 1979; MEB, 2001; Sözer, 1997; Ültanır, 2000'den yararlanılarak oluşturulmuştur.

Tablo incelendiğinde Türkiye'de merkezî yönetimin ve Millî Eğitim Bakanlığı'nın sorumlu ve yetkili kurum olduğu görülmektedir. Almanya ve Danimarka'da ise eğitim yerel yönetimlerce düzenlenmektedir. İngiltere, İspanya, İsveç ve Portekiz'de ise eğitimden hem merkezi hem yerel yönetim söz konusudur. Eğitimde yetkili ve sorumlu kurumların sayısının ülkeden ülkeye değiştiği görülmektedir. Ayrıca bu kurumlar Eğitim Bakanlığı, Eğitim ve Bilim Bakanlığı, Eğitim, Bilim ve Kültür Bakanlığ1, Millî Eğitim Araştırma ve Teknoloji Bakanlığı, Ulusal Eğitim ve Din İşleri Bakanlığı gibi farklı isimler almakla birlikte sorumluluk ve yetkinin birden fazla kurum arasında paylaşıldığı farklı ülkeler de mevcuttur.

Okul yöneticilerinin unvanları ülkeden ülkeye farklılık göstermekle birlikte bazı ülkelerde de aynı ünvanlar kullanılmaktadır. Örnek vermek gerekirse; Almanya ve İsveç'te ilköğretim okul yöneticisine rektör (rector) unvanı verilirken, İspanya ve Fransa'da direktör (director), İngiltere'de ise başögretmen (headteacher) unvanı kullanılmaktadır. Tablo 8'de ülkelere göre ilköğretim ve ortaöğretim kurumlarında okul yöneticilerine verilen adlar sunulmaktadir. 


\section{Tablo 8}

Türkiye ve $A B$ ülkelerinde ilkögretim ve ortaögretimde okul yöneticileri

\begin{tabular}{ll}
\hline Ülke & Okul yönetimi \\
\hline Türkiye & okul müdürü \\
Almanya & rektör+okul konseyi \\
Avusturya & direktör +okul konseyi \\
Danimarka & rektör \\
Finlandiya & yönetim kurulu+öğrenci kurulları \\
Fransa & direktör \\
İngiltere & başöğretmen (headteacher)+yönetim kurulu \\
İspanya & direktör \\
İsveç & rektör \\
Portekiz & direktör \\
Yunanistan & okul müdürü+öğretmenler kurulu \\
\hline
\end{tabular}

Kaynak: Erginer, 2006; DFES, 2004b; Ministère Education Nationale, 2008'den yararlanılarak oluşturulmuştur.

Her ülkede değişik kademedeki okulların yönetiminden sorumlu değişik statüye sahip yöneticiler mevcuttur. Türkiye'de yönetim görevinde bulunanlar okul müdürü, okul müdür yardımcısı, eğitim şefi, bölüm başkanı, dekan, rektör vs. adlarla ifade edilmektedir. Bunlar genellikle bakanlık ya da üst kurullara karşı sorumludur. Bunun yanı sıra değişik ülkelerde okul yöneticisini destekleyen çeşitli organlar bulunmaktadır. Örneğin; Danimarka'da orta öğretim kurumlarında (gymnasium) öğrenci, öğretmen, personel, aile temsilcileri ve kent kurulu temsilcilerinden oluşan bir delegeler kurulu bulunmaktadır. Kurul, okul bütçesi, sınıf büyüklüğü, okulda sunulacak derslerin seçilmesi konularında düzenlemeler yapabilmektedir (Erdoğan, 2006).

Yöneticilerin görev ve yetkileri de kurallarla belirlenmiştir. Her ülkede yasaların yöneticilere vermiş olduğu yetki ve sorumluluğun sınırlan farklılık göstermektedir. Örneğin, Fransa'da okul müdürleri okulun yönetimini ve denetimini yapma, öğretmenlerin çalışmalarını kontrol etme, ders programlarını, ders kitaplarını belirleme, personel alımı, ders araçgereçlerini temin etme, okul-çevre ilişkisini geliştirme vb. görevlerle yükümlüdür (Ministère Education Nationale, 2008).

Bazı ülkelerde okul yöneticisi olmak için öğretmenlik diplomasına sahip olmak gerekmektedir. Bazı ülkelerde ise okul yöneticileri seçimle, yarışma sınaviyla ya da kişisel dosyaların incelenmesi ve mülakat ile belirlenmektedir. Hemen hemen her ülkede okul yöneticilerinin görev ve sorumlulukları benzerdir. Bu görev ve sorumlulukları pek çok ülkede okul 
kurulları paylaşmaktadır. Bazı ülkelerde ise okul yöneticileri denetlenmekte ve değerlendirilmektedir. Örneğin; Almanya'da okul yöneticisinin seçilmesi için kamu ilanına ya da Eyalet Bakanlığı tarafından beceri ve değerlendirmelerin sonuçlarına bağlı olarak mahallî idarelerin önerilerine dayalı olarak atama söz konusudur. Başvuru sahibinin yeteneği, beceri ve uzmanlık bilgisi temelinde seçimini okul kurulları ve okul konseyi (schulkonferenz) yapmaktadır. Almanya'da yöneticiler eyaletin Eğitim ve Kültürel İşler Bakanlığı tarafından atanmaktadır (Erden \& Erden, 2005). Almanya'da okul yöneticileri, eğitimle ilgili tüm konulardan sorumludur. Kararların alınmasında ögrretmenler konseyine ve okul konseyine danışılmaktadır. Almanya'da okul yöneticileri, memur oldukları için kariyerlerinin önemli basamaklarında (terfi, tayin vb.) değerlendirilmektedir. Her eyalette bulunan okul denetleme birimleri denetimden sorumludur (The Education System in Turkey, 2007).

\section{Eğitimin Finansmanı}

En pahalı yatırım olan eğitim, uzun bir zaman dilimini kapsadığı için sürekli ve büyük bir harcamayı zorunlu kılmaktadır. Çalışmanın kapsamı içerisindeki ülkelerin tümünde zorunlu eğitim parasızdır. Bazı giderler ise ilgili otoriteler tarafindan karşılanmaktadır. Tablo 9 ülkelere göre finansman kaynaklarını içermektedir.

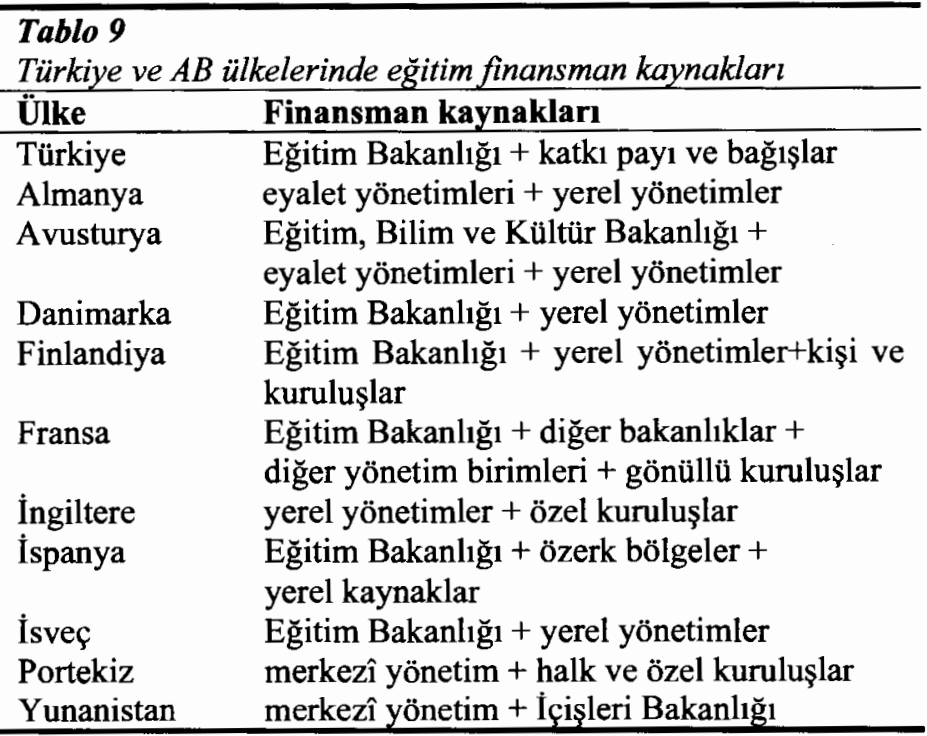

Kaynak: Erdoğan, 2006; Gülcan, 2005; HEFCE, 2008; OECD, 2007; Sözer, 1997; Tuzcu, 2006; Türkoğlu, 1998'den yararlanılarak oluş̧urulmuştur. 
Tablo 9'da da görüldüğü gibi bazı ülkelerde -Türkiye'de olduğu gibimerkezî hükümetler eğitim için giderlerin büyük bir kısmını karşılarken, bazı ülkelerde de merkezî hükümetin yanı sıra eyaletler, yerel yönetimler giderlere yasaların öngördüğü oranlarda katkıda bulunmaktadır. Örneğin Almanya'da eğitimin finansman1; resmî okullar, eyalet yönetimleri ve yerel yönetimlerce ortaklaşa yapılmaktadır. Öğretmen giderleri eyalet yönetimince karşılanırken, okul binalarının yapımı-onarımı ve diğer giderleri yerel yönetimler karşılamaktadır. Federal hükümetin giderlere katılma payı giderek artmaktadır (Sözer, 1997).

Bazı ülkelerde de eğitim giderleri için yasalarla düzenlenen özel gelir kaynakları oluşturulmuş̧ur. Örneğin; Türkiye'de 8 yıllık temel eğitime katkı oluşturmak amacı ile geçici olarak çıkarılan çeşitli mallardan alınan vergilerden oluşan katkı gelirleri daha sonra yeni bir yasal düzenleme ile zorunlu duruma getirilmiştir. Ayrıca, çeşitli ülkelerde bazı okullar döner sermaye esasına göre çalıştıkları için kendileri kaynak oluşturmaktadır. Özellikle yüksek öğrenim düzeyinde batıdaki birçok ülke projelerle yabancı ülke öğrencilerinin eğitimleri ile kaynaklar sağlamaktadır. Bir başka gelir kaynağı da öğrencilerden alınan harçlardır.

Avusturya'da yükseköğretimin finansmanı ulusal bütçeden sağlanan kaynaklarla karşlanmaktadır. Bu bütçeden \%47'si üniversite personeline ayrılmaktadır (İnandı, 2005). Finlandiya'da da yükseköğretimin giderleri devlet bütçesinden sağlanmaktadır. Üniversiteler ayrıca dış finansal kaynaklardan da gelir elde etmektedir (OECD, 2007). İngiltere yükseköğretim kurumlarının ve enstitülerin öğrenim ve araştırma masrafları İngiltere için Yükseköğretim Fon Kurulu (The Higher Education Funding Council for England-HEFCE) tarafindan finanse edilmektedir (HEFCE, 2008).

Tablo 10'da $\mathrm{AB}$ ülkelerinin tümünün tüm düzeylerde eğitime Türkiye'den daha fazla kaynak ayırdığı görülmektedir. Her ülke kendi gelir durumuna göre öğrenci başına düşen harcama miktarını ayarlamaktadır. Örneğin, 2001 rakamlarına göre Almanya'da ilk ve ortaöğretimde öğrenci başına düşen harcama 6055, yükseköğretimde ise 10.504, Finlandiya'da ilk ve ortaöğretimde 5733, yükseköğretimde ise 10.981, Yunanistan'da ise ilk ve ortaöğretimde 3475 , yükseköğretimde ise 4280 dolar öğrenci başına harcama yapılmıştır (Millî Eğitim Bakanlığı [MEB], 2007).

Tablo 10'da GSYİH'nin toplam kamu harcamaları yer almaktadır. 
Tablo 10

AB ülkeleri ve Türkiye'de

GSYIH'nin bir yüzdesi olarak eğitimde kamu harcamaları (2001)

\begin{tabular}{llll}
\hline Ülke & İlk ve ortaöğretim & Yükseköğretim & $\begin{array}{l}\text { Ĕgitimin } \\
\text { tüm düzeyleri }\end{array}$ \\
\hline Türkiye & 2.5 & 1.2 & 3.7 \\
Almanya & 3.0 & 1.2 & 4.6 \\
Avusturya & 3.8 & 1.4 & 5.8 \\
Danimarka & 4.8 & 2.7 & 8.5 \\
Finlandiya & 3.9 & 2.1 & 6.2 \\
Fransa & 4.0 & 1.0 & 5.7 \\
İngiltere & 3.4 & 0.8 & 4.7 \\
İspanya & 3.0 & 1.0 & 4.4 \\
İsveç & 4.8 & 2.0 & 7.3 \\
Portekiz & 4.3 & 1.1 & 5.9 \\
Yunanistan & 2.4 & 1.2 & 3.9 \\
\hline
\end{tabular}

Kaynak: OECD, 2004'den aktaran Çalışkan Maya, 2006.

\section{Eğitimin Teftişi}

Eğitim sisteminin işleyişini belirlemek, tespit edilen amaçlara ulaşıp ulaşılmadığını saptamak amacı ile ya da alanda çalışan öğretmenlere rehberlik etmek gayesi ile teftiş veya denetim adı altında çeşitli kontrol birimleri oluşturulmuştur. Bazı ülkelerde -Türkiye'de olduğu gibi- değişik kademeleri denetleyen müfettiş adı ile anılan ya özel bir örgün eğitimden ya da hizmet içi eğitimden geçirilen görevliler mevcuttur. Türkiye'de ortaöğretimi denetleyen müfettişler ile ilköğretimi denetleyen müfettişlerin görev, amaç, yetişme biçimleri birbirinden farklıdır. Bununla birlikte ülkelere göre denetimin sorumluları da ülkeden ülkeye değişmektedir. Tablo 11 Türkiye ve $\mathrm{AB}$ ülkelerinde denetimden sorumlu kurumlar yer almaktadır. 
Tablo 11

Türkiye ve AB ülkelerinde eğitimin denetiminden sorumlu kurumlar

\begin{tabular}{ll}
\hline Ülke & Eğitimde yetkili/sorumlu kurumlar \\
\hline Türkiye & Millî Eğitim Bakanlı̆̆ı \\
Almanya & Eğitim ve Kültür Bakanlığı \\
Avusturya & Eğitim ve Sanat Bakanlığı \\
Danimarka & Eğitim Bakanlığı \\
Finlandiya & - \\
Fransa & Millî Eğitim Denetleme Kurulu \\
İngiltere & Eğitim Standartlan Ofisi (OFSTED) \\
İspanya & Yüksek Denetleme Kurulu \\
İsveç & Eğitim Bakanlığı+yerel yönetimler \\
Portekiz & Eğitim Genel Teftiş Heyeti \\
\hline
\end{tabular}

(-: kurum bulunmamaktadir)

Kaynak: Gerhard, 2005; Harris, 1993; Johannesson \& diğerleri, 2002; Kodde \& Ritzen, 1994; Süngü, 2005; Yolcu, 2006; The Education System in Turkey, 2007 'dEn yararlanılarak oluşturulmuştur.

Kurumun amaci; bağımsız olarak eğitim standartlarının ve niteliğinin gelişimini sağlamak ve eğitimden sorumlu devlet sekreterine bilgi sunmaktır (Harris, 1993). İsveç'te ise Ulusal Eğitim Ajansı (skolverket) takip geliştirme ve denetleme ile eğitim standartlarını göz önüne sermeye çalışmaktadır. İsveç'te denetim hem kalite kontrolü hem de rehberlik etmeyi amaçlamaktadır. Öğretmenler denetim esnasında oldukça rahattır. Çünkü müfettişlerin görevi teftiş değil rehberlik etmektir (Gerhard, 2005).

Finlandiya'da ise ele alınan diğer ülkelerden farklı olarak ayrı bir okul denetimi mevcut değildir. Eğitim kurumları kendi çalışmalarını ve etkilerini değerlendirmekle yükümlüdür. Eğitimin değerlendirilmesinin amac1 kanunda belirtilen hedeflere ulaşıldığından emin olmak ve eğitimin gelişimini desteklemenin yanında öğrenme fırsatlarını da geliştirmektir. Bu ülkede okulların kendi kendilerini değerlendirmeleri, kanun ve sözlü uygulamalarla gitgide daha da yerleşmektedir. Okul yasası, kendi kendilerini değerlendirmeyi her okul için resmî bir sorumluluk haline getirmiștir (Johannesson \& diğerleri, 2002).

\section{Öğretmen Eğitimi}

Bu çalışmanın kapsamı içinde yer alan ülkelerde öğretmen yetiştirme düzeni açısından da süre, içerik, öğrencinin geldiği kaynak bakımından farklılıklar vardır. Hemen hemen tüm ülkelerde her kademe ve her tür okul için öğretmen yetiştirme programlarının birbirinden farklı olduğu söylenebilir. Ancak her öğretmen eğitimi programında genel kültür, alan 
bilgisi ve meslekî formasyon (pedagojik formasyon) ders gruplan değişik kredi ve ağırlıklarda bulunmaktadır. Öğretmen yetiştiren okullara girişte bazı ülkelerde -Türkiye'de olduğu gibi- sınavla, bazı ülkelerde ise ortaöğretim not ortalaması ile birlikte sınav da yapılmaktadır. Öğretmen yetiştiren okulların öğrenim süreleri Türkiye'de olduğu gibi 4 ile 5 yıl arasında değişmektedir.

Diploma derecesi bakımından da okullarda çalışan öğretmenler genellikle lisans mezunudur. Ancak ön lisans ve lisansüstü mezunu olan öğretmenlerin çalıştı̆gı ülkeler de mevcuttur. Örneğin; Yunanistan'da önceleri ortaöğretim I. ve II. devre okullarındaki (gymnasio ve lykeio) alan öğretmenliği için, ilgili alan fakültelerinde 4 yıllık öğrenim görmüş olmak yeterli bulunurken 2003 yılından itibaren 4 yıllık alan öğretiminden sonra 1 yıl süreyle öğretmenlik meslek bilgisi öğrenilmesi zorunluluğu getirilmiştir. Finlandiya'da da öğretmenlik eğitiminin süresi beş yıldır ve öğretmenlik mesleği Fin toplumunda en önemli mesleklerden biri olarak algılanmaktadır. Ögretmenlere gerçek profesyoneller olarak en iyisini yapacakları konusunda sonsuz bir güven duyulmaktadır. Sınıfta öğretmenlere kayda değer bir pedagojik bağımsızlık verilmiştir. Maaşların miktarı diğer Avrupa ülkelerinin bazılarından düşük olmasına rağmen öğretmenlik başvurularının sadece \%15'i kabul edilmektedir. Aynca öğretmenlik yapabilmek için mutlaka yüksek lisans mezuniyet derecesini almış olmak gerekmektedir (Linnkylä, 2004).

\section{Sonuç ve Öneriler}

Bir sistemi oluştururken her toplum kendi değerlerinden hareket etmek durumundadır. Toplumsal gerçekleri göz önüne almadan oluşturulan ya da başka ülkelerden transfer edilen sistemlerin kısa dönemde ihtiyaçlara cevap vermediği pek anlaşılmaz. Çünkü girdinin ürüne dönüşmesi uzun bir süreci gerektirir. Uzun dönemde işe yaramadığı anlaşılan sistem değiştirilse bile toplumda büyük zaman, enerji, para, insan kayıplarına yol açması kaçınılmaz olur. Günümüzde genellikle gelişmekte olan bazı ülkeler kendi eğitim sistemlerini oluşturmak yerine kolaycılığa kaçarak gelişmiş olan bir başka ülkenin eğitim sistemini kısmen ya da tamamen alarak çoğu zaman da hiç uyarlamaya bile gerek duymadan uygulama gayreti içine girmektedir.

Çalışmanın konusu kapsamında değerlendirilen değişik gelişim düzeyleri ve sosyo-ekonomik yapıda bulunan ülkelerin genelde eğitim sistemlerinin birbirinden farklı olduğu görülmektedir. Her ülke kendi sistemini iç dinamiklerine bağlı olarak oluşturma çabası içerisindedir. Bu çalışmada, Türkiye ve on $\mathrm{AB}$ ülkesinde karmaşı ve dinamik bir özellik taşıyan eğitim olgusu belirli başliklar halinde incelenmiştir. Gelişmiş ülkelerin eğitim 
sistemleri incelendiğinde kendilerine has bir yapının olduğu açık bir şekilde görülmektedir. Çalışmada incelenen Almanya eğitim sistemi, İsveç eğitim sistemi, özellikle de son yıllarda uluslar arası sınavlarda büyük başarı gösteren Finlandiya eğitim sistemi özgün olma özelliğini taşıyan ülkelerin başında gelmektedir. Böylece çalışmada tek bir eğitim sistemi, modelinin olmadığını ortaya konulmuş ve Türkiye için bu sonuçlardan ne gibi öneriler getirilebileceği aşağıda belirtilmeye çalışılmıştır. Çalışmadan elde edilen verilere bağlı olarak getirilebilecek öneriler şunlar olabilir:

- $A B$ ülkelerinde dört yaş okullaşma oranları oldukça iyi durumda olmasına karşın Türkiye'de bu yaş için verilerin bulunmaması ilgi çekicidir. Türkiye'de okulöncesi eğitimde okullaşma oranları yaşlar itibariyle tespit edilmelidir. Türkiye'de okul öncesi eğitimde iyileştirme çabaları arttırılmalıdır.

- Zorunlu eğitim yaşı $\mathrm{AB}$ ülkeleri ile karşıllaştırıldığında en düşük zorunlu eğitim, 8 yıllık eğitim süresi ile Türkiye'nindir. Zorunlu eğitim süresi Türkiye'de altyapısı iyi hazırlanarak tekrar düzenlenmelidir.

- Zorunlu eğitim okullaşma oranları $\mathrm{AB}$ ülkelerinden Fransa ve Portekiz'de \%100'e ulaşmış, ortalama okullaşma oranı ise $A B$ ülkelerinde $05-14$ yaş arası \%99.4'e varmıştır. Türkiye'de okullaşma oranları için yaşlara göre veriler belirlenmeli okullaşma oranlarını arttırmak için işlevsel önlemler alınmalıdır.

- Türkiye'de haftalık ders saati $\mathrm{AB}$ ülkeleri ile karşılaştırıldığında daha fazladır (30 saat). Haftalık ders saati sayısı tekrar incelenebilir. Öğretmenlere ders saatleri açısından serbestlik sunulabilir. $\mathrm{AB}$ ülkelerinde sömestr süresi bizdeki kadar uzun değildir. Türkiye'de tatil süreleri tekrar gözden geçirilebilir.

- Türkiye'de ortaöğretimden üniversiteye geçiş koşulları, sadece üniversite sınavı ile seçimde adaylarda aranan çeşitli nitelikler ölçülemediğinden bu konuda yeni düzenlemeler getirilebilir.

- Yetişkin eğitimi için $\mathrm{AB}$ ülkelerinde oranlara bakıldığında 40 yaş ve üzerinde bile ortalama \%2.1 oranında okullaşmanın olması söz konusudur. Türkiye'de ise bu yaşlar arası veriler bulunmamaktadır. Türkiye'de yetişkin eğitiminin durumu gözden geçirilmeli ve iyileştirilmelidir. 
- $\quad \mathrm{AB}$ ülkelerinden bazıları merkezî, bazıları yerel, bazıları ise hem merkezî hem yerel yönetimi uygulamaktadır. Türkiye'de ise merkezî yönetim söz konusu olmakla birlikte ülkemizin her yerinde eğitimde nitelik farklılıklarının olduğu da bir gerçektir. Türkiye için diğer yönetim şekillerinin uygun olup olamayacağı üzerinde düşünülmelidir.

- $\quad \mathrm{AB}$ ülkeleri ile karşılaştırıldığında Türkiye'de eğitime yeteri kadar maddî kaynak ayrılmadığı görülmektedir. Türkiye'de eğitim, finansman açısından güçlendirilmelidir.

- Ülkeler arasında eğitimin denetiminde önemli farklilıklar bulunmaktadır. İsveç’te denetim, öğretmenler kendilerini geliştirici bir çalışma olarak algıladıkları için oldukça olumlu bir bakış açısı ile ve rahat bir ortamda yapılmakta iken, Finlandiya'da ise dıştan eğitimi denetleyecek bir otoriteye ihtiyaç duyulmamaktadır. Türkiye'de ise denetim müfettişlerce Millî Eğitim Bakanlığ1 tarafından yapılmakta fakat denetimin niteliği tartışılır bir durum arz etmektedir. Türkiye'de eğitimin denetimi eleştirel odaklı olmak yerine niteliği arttırıcı şekilde tekrar ele alınmalıdır.

- $\quad \mathrm{AB}$ ülkelerinin bazılarında öğretmen eğitimi yüksek lisans düzeyinde yapılmakta ve böylece öğretmenler sınıflarında etkin uygulamalar yapabilecek şekilde donatılmaktadır. Türkiye'de de bu anlamda kalitenin ve öğretmenlik mesleğinin statüsünün arttırılmasına yönelik çalışmalar yapılmalıdır.

Ülkeler karşılaştırmalı eğitimin kapsamı içerisinde birbirlerinin eğitim sistemlerini inceleyip kendi modellerini oluşturmada diğerlerinden esinlenebilirler. Ancak hiçbir ülke bir başka ülkenin eğitim sistemini olduğu gibi alma hatasına düşmemelidir. Genellikle başka ülkeleri kopya alarak eğitim sistemlerini düzenleyen ülkeler uzun zaman dilimi içerisinde gelişmekte olan ülkeler kategorisinden kurtulamamıştır. 


\section{Kaynakça:}

Ada, S. (2007). 'Türkiye'de ve Dünya'da ilköğretimin tarihsel gelişimi'. Ayla Oktay ve Özgül Polat Unutkan (Ed.), İlköğretim çağına genel bir bakış içinde. İstanbul: Morpa Yayınları.

Bentolila, S., \& Jimeno, J.F. (1998). Regional unemployment persistent: Spain 1976-1994. Labour Economic, 5.

Broadfoot, P. (2000). Comparative education forthe 21 st century: retrospect and prospect. Comparative Education, Aug., 36(3), 357-372.

Çalışkan Maya, İ. (2006). AB sürecinde Türkiye ile $\mathrm{AB}$ ülkeleri eğitim istatistiklerinin karşılaştırılması. Türk Eğitim Bilimleri Dergisi, 4(4), 375-394.

Demirel, Ö. (1998). Karşılaştırmalı eğitim. Ankara: Kardeş Kitap ve Yayınevi.

DFES (2004a). National Curriculum. Retrieved: August 21, 2004 from http:/www.dfes.gov.uk

DFES (2004b). Department for Children, Schools and Families. Retrieved: October 09, 2004, from http://www.dfes.gov.uk

Diplôme National du Brevet (2008). Retrieved: August 17, 2008 from http://www.education.gouv.fr /cid2619/diplome-national-du-brevet.html

Doğan, E. (2002). Avusturya eğitim sistemi. Erişim: 17 Ocak 2008 from http://www.ogretmenlik.com/avusturya.htm

Education system in Finland (2006). Eurybase the information database on education systems in Europe. Retrieved: September 03, 2007 from http://www.Eurydice.org/portal/Eurydice/ByCountryResults?CountryC ode $=$ FI

Erden, A., \& Erden, H. (2005). Avrupa Birliği Ülkeleri'nde okul yöneticileri. Milli Eğitim Dergisi, 33(167). Erişim: 20 Mart 2008 from http://yayim.meb.gov.tr/dergiler/167/index3-erden.htm

Erdoğan, İ. (2006). Çağdaş eğitim sistemleri (6. basım). İstanbul: Sistem Yayıncilik.

Erginer, A. (2006). Avrupa birliği eğitim sistemleri (1. basım). Ankara: PegemA Yayıncılık. 
Eurydice (2007a). Avrupa'daki Eğitim Sistemleri Üzerine Özet Belgeleri Danimarka. Retrieved: October 21, 2007 from maol.meb.gov.tr/html_files/ulkeler/Denmark\%20(TR).doc

Eurydice (2007b). Avrupa'daki eğitim sistemleri üzerine özet belgelerİsveç. Erişim: 19 Ekim 2007 from http://megep.meb.gov.tr/megeb/genel/moduler/ulkeler/Sweden\%20(TR) .doc

Eurydice (2008a). Avrupa'daki Eğitim Sistemleri Üzerine Özet Belgeleri Portekiz. Retrieved: January 28, 2008 from maol.meb.gov.tr/html_files/ulkeler/Portugal\%20(TR).doc

Eurydice (2008b). Avrupa'daki Eğitim Sistemleri ve Sürdürülmekte Olan Reformlar Üzerine Ulusal Özet Belgeleri Finlandiya. Retrieved: January 28, 2008 from maol.meb.gov.tr/html_files/ulkeler/Finland\%20(TR).doc

Gerhard, P. (2005). P2P project inspectorate stand meeting in brussels.

Erişim: 08 Ekim 2008 from http://europeanschoolnet.org/ww/ en/pub/eun/news/news_headlines/703.htm

Gülcan, M. G. (2005). AB ve eğitim süreci. Ankara: Anı Yayıncılık.

Gültekin, M. (1998). 'Türkiye ve Avrupa Birliği üye bazı ülkelerde zorunlu eğitim'. Ayhan Hakan (Ed.), Ĕgitim Bilimlerinde Yenilikler içinde. Eskişehir: Anadolu Üniversitesi Yayınları.

HEFCE (2008). Higher Education Funding Council for England. Retrieved: January 28, 2008 from http://www.hefce.ac.uk

İnandı, Y. (2005). 'Avrupa Birliği Ülkeleri eğitim sistemi ile Türk eğitim sisteminde eğitimin yönetimi ve finansmanı'. Yayınlanmamış Doktora Tezi. İstanbul: Marmara Üniversitesi Eğitim Bilimleri Enstitüsü.

Johannesson et al. (2002). An inevitable progress? educational restructuring in Finland, Iceland and Sweden at the turn of the millenium. Scandinavian Journal of Educational Research, 3(46).

Harris, N. (1993). Law of education: regulation, consumerism and the education system. London: Sweet-Maxwell.

Kilimci, S. (2006). 'Almanya, Fransa, İngiltere ve Türkiye'de sınıf öğretmeni yetiştirme programlarının karşılaştırılması'. Yayınlanmamış Doktora Tezi. Adana: Çukurova Üniversitesi Sosyal Bilimler Enstitüsü.

Karacaoğlu, Ö. C., \& Çabuk, B. (2002). İngiltere ve Türkiye eğitim sistemlerinin karşılaştırılması. Millî Ĕ̆itim Dergisi, 155-156. 
Kodde, A., \& Ridzen J. (1994). Direct and Indirect effects of parental education level on the demand for higher education. The Journal of Human Resources, 28(4).

Lauwers, J. A., \& diğerleri (1979). Mukayeseli eğitim (2. basım). Ankara.

Lappalainen, S. (2006). Liberal multiculturalism and national pedagogy in a finnish preschool context: inclusion or nation-making. Department of education, University of Helsinki, Pedagogy, Culture Society, 1(14).

Laycock, L. (2002). 'Primary School'. L. Gearon (eds), Education in the United Kingdom. London: David Fulton Publisher.

Linnkylä, P. (2004). Finnish education-reaching high quality and promoting equity. Education Review, Education Journal, 2(17).

Millî Eğitim Bakanlığı (2001). 2002 yılı başında Millî Eğitim. Ankara: MEB.

Millî Eğitim Bakanlığı (2006). Türkiye ve Avrupa Birliği ülkelerinin eğitim sistemleri. Ankara: MEB.

Millî Eğitim Bakanlığı (2007). Avrupa'da eğitime ilişkin temel veriler 2005. Ankara: MEB.

Ministère Education Nationale (2008). Retrieved: August 21, 2008 from http://www.education.gouv.fr

Moon, B. (2001). A guide to the national curriculum. Oxford: Oxford University Pres.

Northern Ireland Goverment, Department of Education (2001). 'Study visit to Austrial'. Retrieved: January 22, 2008 from http://www.deni.gov.uk/22-ppa_burnsreport_studyvisitaustria.pdf

OECD (2007). Attracting, Developing and Retaining Effective Teachers. Retrieved: September 03, 2007 from http://www.oecd.org/dataoecd/43/15/5328720.pdf

Öz, V. (2001). Sorularla Alman eğitim sistemi. Almanya: T.C. Mainz Başkonsolosluğu Eğitim Ateşeliği.

Pökön, A. (2003). 'Fransa ve Türkiye Okul Öncesi Eğitim Sistemlerinin Karşılaştırmalı Olarak İncelenmesi'. Yayınlanmamış Yüksek Lisans Tezi. İstanbul: Marmara Üniversitesi, Eğitim Bilimleri Enstitüsü. 
Süngü, H. (2005). 'Fransa, İngiltere ve Almanya eğitim denetimi sistemlerinin karşılaştırmalı olarak incelenmesi'. Yayınlanmamıs Yüksek Lisans Tezi. İstanbul: Marmara Üniversitesi, Eğitim Bilimleri Enstitüsü.

Sözer, E. (1997). Ü̧̧ Avrupa ülkesinde eğitim. Eskişehir: Anadolu Üniversitesi Eğitim Fakültesi Yayınları.

Sutton, M., Post, D., Merkxi, G. W. et al. (2006). Comparative education, area studies and the disciplines/ first round response. Comparative Education View, Feb., 50(1), 125-148.

The Education System in Turkey. Retrieved: December 10, 2007 from http://eacea.ec.europa.eu/portal/page/portal/Eurydice/EuryContents?country $=T R \&$ lang $=\mathrm{EN} \&$ expandMenu $=$ false

Türkoğlu, A. (1998). Karşılaştırmall eğitim 'dünya ülkelerinden örneklerle'. Adana: Baki Kitabevi.

Ültanır, Y. G. (2000). Karşılaştırmall eğitim bilimi kuram ve teknikler. Ankara: Eylül Yayınları.

Tuzcu, G. (2006). Avrupa birliğine giriş süreci ve eğitimde vizyon 2023. Ankara: Türk Eğitim Derneği Yayını.

Yıldırım, M. C. (2008). Avrupa birliği ülkelerinde ve Türkiye'de okul öncesi eğitim. Elektronik Sosyal Bilimler Dergisi, 7(25). Erişim: 25.10.2008, from http://www.e-sosder.com/dergi725091-110pdf

Yolcu, H. (2006). Avusturya Eğitim Sistemi. Eğitim ve Denetim Dergisi, $4(12)$. 